\title{
Stereological Evaluation of the Effects of Momordica charantia, antioxidants and Testosterone on Seminiferous Tubules of Rat
}

\author{
Evaluación Estereológica de los Efectos de Momordica charantia, \\ Antioxidantes y Testosterona sobre los Túbulos Seminíferos de Rata \\ Oshiozokhai Eboetse Yama; Francis Ikechukwu Duru; \\ Ademola Ayodele Oremosu; Cressie Carmel Noronha \& Abayomi Okanlawon
}

\begin{abstract}
YAMA, O. E.; DURU, F. I.; OREMOSU, A. A.; NORONHA, C. C. \& ABAYOMI, O. Stereological evaluation of the effects of Momordica charantia, antioxidants and testosterone on seminiferous tubules of rat. Int. J. Morphol., 29(3):1062-1068, 2011.

SUMMARY: Ubiquitous consumption of Momordica charantia is hinged on credence of its potency in alleviating ailments. Almost no data exist on its quantitative relationship to the testes. The aim was to study the histomorphometric effect of Momordica charantia seed extract (MC), ascorbic acid (C), alpha-tocopherol (E) and testosterone (T) on the testes of rats. Ninety five mature 6-8 week-old male Sprague-Dawley (S-D) rats allotted randomly into six groups. Group I: fed MC for 16 weeks. Group II: administered MC for 8 weeks, later distilled water for another 8 weeks. Group III: administered C, E, T and a combination of all three test solutions (CET) for 8 weeks and later fed MC for another 8 weeks. Group IV: received MC initially for 8 weeks and later administered C, E, T and CET for another 8 weeks. Group V: fed concurrently the extract, C, E, T and CET for 8 weeks. Group VI (control): administered C, E, T, CET and distilled water for 16 weeks. The doses for MC, C, E and T were $50 \mathrm{mg} / 100 \mathrm{~g} \mathrm{b.w} / \mathrm{oral} / \mathrm{day}, 0.01,20.0 \mathrm{and} 0.05 \mathrm{mg} / \mathrm{kg}$. The animals were sacrificed; testes estimated for volume. Diameter, cross sectional area (AC), number of profiles per unit area (NA), length density $(\mathrm{LV})$ and numerical density (NV) of the seminiferous tubules determined. The mean testicular volumes, tubular diameters and AC showed significant decline ( $\mathrm{p} \leq 0.05)$ in Groups I and III compared to controls. On cessation of MC values recovered to baseline control value. Groups IV and V, were not significantly $(\mathrm{p} \leq 0.05)$ different from controls. There was a significant $(\mathrm{p} \leq 0.05)$ increase in NA, LV and NV of seminiferous tubules in Groups I and III compared to controls. Histomorphometric data supports a reversible deleterious effect of MC on testes.
\end{abstract}

KEY WORDS: Histomorphometric; Momordica charantia; Sprague-Dawley; Testes.

\section{INTRODUCTION}

Herbal recipes have been used since time immemorial to hinder reproduction; with most preparations targeted at plummeting female fertility. After Henshaw's work in 1953, there has been a steady accumulation of information regarding the screening of plants having male antifertility efficacy. The effects of these plants on such subjects were frequently evaluated measuring the hormonal profile, seminal fluid analysis and biochemical parameters (Henshaw, 1953).

A brief review of publications of Momordica charantia (MC) on its relationship to the reproductive system reveals also a constant attention on the female rats. The seed has been shown to induce abortion in gestational mice. The roots documented to possess uterine stimulant effect also reputed for its aphrodisiac property (Koller, 2009). The fruit and leaf has exhibited an in-vivo female antifertility effect; even though the fruit was not found to induce miscarriage, safety a margin in pregnancy was yet to be established (Raintree Nutrition, Tropical Plant Database, 2008). On the male reproductive effect of this plant; there exists a dearth of literature while almost none on the cytometric quantification (counting and measuring of cells). However, in one study various extracts (ether, benzene and alcohol) of MC seeds were administered orally and intraperitoneally to male rats for 35 days. All three extracts demonstrated prevailing antispermatogenic activity, the most potent being ethanol extract. Again the effects on the male rats were assessed by measuring the testicular weights and biochemical assay (Naseem et al., 1998). 
Antioxidants are known to ameliorate the damaging effects of various testicular toxicants (Fakin et al., 1986; Rao et al., 2005). When given as supplement to male Wistar rats was shown to significantly improve epididymal sperm concentration and plasma testosterone levels (Sönmez et al., 2005). Ascorbic acid (C) had the added benefit of preventing sperm head to head agglutination by its antioxidant effect on non specific sperm agglutinin which then enhances sperm motility and subsequently fertility (Rolf et al., 1999). The addition of alpha-tocopherol (E) is shown to lower the levels of malondialdehyde and increase the ability of spermatozoa to fuse with oocytes. An in-vivo clinical study (Kessopoulou et al., 1995) also suggested that its supplementation aids in fertilization. The sexual and copulatory behaviors of male on the other hand depend on gonadal androgen secretion (Hull \& Dominguez, 2007). It declines in the absence of testosterone $(\mathrm{T})$ and is restored with replacement.

This present study examines the stereological responses of the testes to high dose $M C$ seed extract administered daily for 8 to 16 weeks; also the prophylactic, modulating and 'therapeutic' effects of test solutions (antioxidants \& T) on the testes of Sprague-Dawley rats (S-D).

\section{MATERIAL AND METHOD}

Sources, maintenance of animals: Ninety five male 6-8 week-old S-D rats were used for the study. They were acquired from the Animal house of the Faculty of Basic Medical Sciences University of Lagos and authenticated by a taxonomist (Malaka, 2005) at the Zoology Department of the same University. The rats were divided randomly into 6 groups: named; Treated, Withdrawal, Prophylactic, Postexposure treated, Modulating and Control groups respectively. All the animals were housed in well ventilated plastic cages in the animal room of the Department of Anatomy College of Medicine University of Lagos. Here, normal standard ambient conditions of temperature between 28-31oC, relative humidity between $50-55 \%$ and a photoperiodicity of $12 \mathrm{~h}$ natural light and $12 \mathrm{~h}$ dark. They were weighed at procurement and at weekly interval. They had access to rat chow (Livestock feeds Plc. Ikeja, Lagos, Nigeria) and water ad libitum.

Identification and preparation of Momordica charantia seed extract: The ripe fruits of $M$. charantia harvested in month of August were purchased from the local market in Lagos Nigeria. It was authenticated by a taxonomist in the Forest Herbarium Ibadan (Botany Department) University of Ibadan, where the voucher specimen deposited (ascension No FHI 108422). The seeds were dried in an oven (temperature of between $30-38 \mathrm{C}^{\circ}$ ) for a week. They were weighed and Soxhlet extraction done the percentage yield obtained was $23.0 \% \mathrm{w} / \mathrm{w}$.

Determination of the LD50 of MC seed extract: This was done using the fixed-dose procedure described by Walum (1998). Briefly; the extract was given at one of three fixed doses at a time to 5 males S-D. At the dose of $460 \mathrm{mg} / 100 \mathrm{~g}$ there were clear signs of toxicity with mortality of $50 \%$ of the rats. The dose $50 \mathrm{mg} / 100 \mathrm{~g}$ body weight of $M C$ extract was chosen. A metal canula was used to administer the extract orally by gastric gavages, done between 13.00-16.00 hours daily.

Dosage, route and duration of administration of test solutions: These were selected in order to simulate those of human. The dosages for C, E and T were; 0.01, 20 and 0.05 mg/kg (Mishra \& Acharya, 2004; Helzlsouer et al., 2000; Osinubi, et al., 2006). T was administered as testosterone proprionate (TP), suspended in arachis oil from which apposite volumes calculated. The following regimen were adopted; $\mathrm{C}$ and $\mathrm{T}$, given three times a week, Monday, Wednesday and Friday; E given five days a week Monday, Tuesday, Wednesday, Thursday and Friday. The dosages were calculated by simple proportion based on the animal's individual weekly weights and appropriate aliquots approximated to the nearest numeral administered intramuscular into the hamstring muscle. The same total duration was adopted for both experimental and controls to address the confounding effect of age; equivalent to two spermatogenic cycles of 16 weeks in rats (Jegou et al., 2002).

Experimental protocol and necropsy schedule: The Treated group (MC)16WK were fed Momordica charantia extract for 16 weeks. The Withdrawal group (MC8DW 8 )16WK administered the extract for 8 weeks; discontinued and fed equal volumes of distilled water for another 8 weeks. Both groups comprised 5 rats each. The Prophylactic, Post-exposure treated and Modulating groups were further randomized into 4 subgroups of 5 rats. The Prophylactic subgroups include: (C8-MC8)16WK, (E8MC8)16WK, (T8-MC8)16WK and (C,E,T8-MC8)16WK administered initially $\mathrm{C}, \mathrm{E}, \mathrm{T}$ and a combination of all three (CET) for 8 weeks and later fed $M C$ extract for another 8 weeks. The Post-exposure treated subgroups viz: (MC8C8)16WK, (MC8-E8)16WK, (MC8-T8)16WK and (MC8$\mathrm{C}, \mathrm{E}, \mathrm{T} 8) 16 \mathrm{WK}$ received $M C$ initially for 8 weeks and later administered C, E, T and CET respectively for another 8 weeks. The Modulating subgroups: $(\mathrm{MC}+\mathrm{C}) 16 \mathrm{WK}$, $(\mathrm{MC}+\mathrm{E}) 16 \mathrm{WK},(\mathrm{MC}+\mathrm{T}) 16 \mathrm{WK}$ and $(\mathrm{MC}+\mathrm{C}, \mathrm{E}, \mathrm{T}) 16 \mathrm{WK}$ were administered $\mathrm{MC}$ and test solutions (C, E, T and CET) concurrently for 8 weeks. The control rats comprised 5 subgroups of 5 rats each: C16WK, E16WK, T16WK, 
C,E,T16WK and DW16WK, administered C, E, T, CET and distilled water for 16 weeks. At the end of the experimental duration (16 weeks), the rats were sacrificed by cervical dislocation. This was followed by a ventral laparotomy to deliver the testes per abdomen which was processed for morphometric studies.

Measurement of testicular volume: This was estimated by water displacement method using Archimedes principle (Acott, 1999). The two testes of each rat were measured and the average value obtained for each of the two and parameters regarded as one observation, the values expressed as $\mathrm{g} / 100$ $\mathrm{g}$ body weight.

Testicular sampling technique: Random sampling was the basis for tissue selection; each fixed testis was cut into roughly $1-\mathrm{cm}$ thick slabs which were subsequently diced at approximately $1 \mathrm{~mm}$ edge length. These were sampled by the lottery method and post-fixed in Bouin's solution, dehydrated in ascending concentrations of ethyl alcohol. They were then processed for light microscopy. Physical randomization of tissue orientation was introduced by allowing diced testis samples to settle haphazardly in the embedding medium. This approach is not as rigorous as using vertical sectioning with sine-weighted test lines (Baddeley et al., 1986). However, the dispositions and orientations of seminiferous tubules and their components are sufficiently variable that they are unlikely to compromise the aim of meeting the requirements of random location and isotropy for unbiased estimates (Østerby \& Gundersen, 1988; CruzOrive, 1989; Mayhew, 1992). In several tubular sections cut at random positions, the requirement of random orientation between ingredients and section planes is likely to be met.

Stereological tools: These were actually mathematically proven relationships (Howard \& Reed, 2005) which measured the geometric changes of the vertical sections of seminiferous tubules of the testes. For each testis, seven vertical sections from the polar and the equatorial regions were sampled, using a systematic random scheme that ensured fair distribution between the polar and equatorial regions of each testis. An unbiased numerical estimation of the morphometric parameters was then calculated. They include evaluation of diameter (D), cross-sectional area (AC), number of profiles in a unit area of testis (NA), numerical density (NV) and length density (LV) of the seminiferous tubules.

Diameter of seminiferous tubules: Round or elliptical tubule profiles with a clear lumen were sampled using a test frame according to the unbiased forbidden-line rule, and their diameter of a circular profile was measured (Gundersen \& Jensen, 1987). The diameter of seminiferous tubules with profiles that were round or nearly round were measured and the mean determined by taking the average of two diameters at right angles, D1 and D2. They were taken only when D1 / D2 П $0.85(1.0=$ a perfect circle $)$. This is to eliminate longitudinal profiles which might exhibit different degrees of damage along their length and/or show irregular shrinkage.

Cross-sectional area of the seminiferous tubules: It was determined by multiplying the mean of the squared diameters by a constant ( $\mathrm{p} / 4$ ). $\mathrm{AC}=\mathrm{D} 2 \mathrm{Xp} / 4$ (where $\mathrm{p}$ is equivalent to 3.142 and $\mathrm{D}$ is the mean diameter of the seminiferous tubules).

Number of profiles of seminiferous tubules in a unit area of testis: This was determined by using the unbiased counting frame proposed by Gundersen (1977). Using this frame, in addition to counting profiles completely inside the frame we counted all profiles with any part inside the frame provided they do not touch or intercept the forbidden line (full-drawn line) or exclusion edges or their extension.

Numerical density of the seminiferous tubules: This is the number of profiles per unit volume and was determined by using the modified Floderus equation: $\mathrm{NV}=\mathrm{NA} /(\mathrm{D}+\mathrm{T})$ (Gilliland et al., 2001). Where NA is the number of profiles per unit area, $\mathrm{D}$ is the diameter and $\mathrm{T}$ is the average thickness of the section.

Length density of the seminiferous tubules: This is the length of profile per tissue volume and was determined by using the following equation, $2 \times \mathrm{NA}$.

Statistical analysis. Results were expressed as mean \pm standard deviation. Analysis was carried out using analysis of variance (ANOVA) with Scheffe's post hoc test. The level of significance was considered at $\mathrm{p}<0.05$. All procedures involving animals in this study conformed to the guiding principles for research involving animals as recommended by the Declaration of Helsinki and the Guiding Principles in the Care and Use of Animals (World Medical Association \& American Physiological Society, 2002) and were approved by the Departmental Committee on the Use and Care of Animals in conformity with international acceptable standards.

\section{RESULTS AND DISCUSSION}

Stereology the science of measurement of structure has a uniqueness of clarity; its unbiased methods give confidence that the estimation is reliable. It eliminates the limitations associated with assumption based technique and two-dimensional representation methods deployed in assessing microscopic tissues (Mouton, 2002). 
Table I. Seminiferous tubular diameter, number of profiles per unit area and testicular volume in experimental and control SpragueDawley rats.

\begin{tabular}{|c|c|c|c|c|}
\hline Groups $(n=95)$ & Group detail & $D(\mu m)$ & $N_{A}\left(x 10^{8}{ }_{-} m^{-2}\right)$ & Volume (ml) \\
\hline Treated & $(\mathrm{MC})_{16 \mathrm{WK}}$ & $73.12 \pm 2.32^{\mathrm{b}}$ & $94.00 \pm 28.13^{b}$ & $0.33 \pm 0.29^{b}$ \\
\hline Withdrawal & $\left(\mathrm{MC}_{8}-\mathrm{DW}_{8}\right)_{16 \mathrm{WK}}$ & $212.54 \pm 10.08$ & $18.80 \pm 3.11$ & $1.42 \pm 0.42$ \\
\hline \multirow[t]{4}{*}{ Prophylactic } & $\left(\mathrm{C}_{8}-\mathrm{MC}_{8}\right)_{16 \mathrm{WK}}$ & $87.45 \pm 7.00^{\mathrm{b}}$ & $104.25 \pm 11.62^{\mathrm{b}}$ & $0.57 \pm 0.13^{\mathrm{b}}$ \\
\hline & $\left(\mathrm{E}_{8}-\mathrm{MC}_{8}\right)_{1_{6 \mathrm{WK}}}$ & $71.80 \pm 3.31^{\mathrm{b}}$ & $96.50 \pm 4.65^{\mathrm{b}}$ & $0.38 \pm 0.18^{\mathrm{b}}$ \\
\hline & $\left(\mathrm{T}_{8}-\mathrm{MC}_{8}\right)_{16 \mathrm{WK}}$ & $74.08 \pm 6.01^{\mathrm{b}}$ & $90.00 \pm 3.83^{\mathrm{b}}$ & $0.53 \pm 0.19^{b}$ \\
\hline & $\left(\mathrm{C}, \mathrm{E}, \mathrm{T}_{8}-\mathrm{MC}_{8}\right)_{1_{6 \mathrm{WK}}}$ & $81.58 \pm 11.59^{\mathrm{b}}$ & $66.75 \pm 19.60^{\mathrm{b}}$ & $0.57 \pm 0.31^{\mathrm{b}}$ \\
\hline \multirow[t]{4}{*}{ Post Exposure Treated } & $\left(\mathrm{MC}_{8}-\mathrm{C}_{8}\right)_{16 \mathrm{WK}}$ & $215.17 \pm 12.67$ & $43.67 \pm 3.79$ & $0.93 \pm 0.06$ \\
\hline & $\left(\mathrm{MC}_{8}-\mathrm{E}_{8}\right)_{16 \mathrm{WK}}$ & $210.10 \pm 9.89$ & $40.50 \pm 19.74$ & $0.91 \pm 0.08$ \\
\hline & $\left(\mathrm{MC}_{8}-\mathrm{T}_{8}\right)_{1_{6 \mathrm{WK}}}$ & $232.80 \pm 47.58$ & $24.00 \pm 6.32$ & $0.93 \pm 0.06$ \\
\hline & $\left(\mathrm{MC}_{8}-\mathrm{C}, \mathrm{E}, \mathrm{T}_{8}\right)_{16 \mathrm{WK}}$ & $225.70 \pm 9.40$ & $24.00 \pm 3.39$ & $0.99 \pm 0.16$ \\
\hline \multirow[t]{4}{*}{ Modulating } & $(\mathrm{MC}+\mathrm{C})_{1_{6 \mathrm{WK}}}$ & $177.83 \pm 7.51$ & $49.00 \pm 21.38$ & $1.17 \pm 0.30$ \\
\hline & $(\mathrm{MC}+\mathrm{E})_{1_{6 \mathrm{WK}}}$ & $184.86 \pm 6.03$ & $39.40 \pm 12.72$ & $1.12 \pm 0.22$ \\
\hline & $(\mathrm{MC}+\mathrm{T})_{16 \mathrm{WK}}$ & $178.90 \pm 1.87$ & $29.40 \pm 6.11$ & $1.05 \pm 0.25$ \\
\hline & $(\mathrm{MC}+\mathrm{C}, \mathrm{E}, \mathrm{T})_{16 \mathrm{WK}}$ & $200.18 \pm 2.01$ & $27.50 \pm 7.23$ & $1.11 \pm 0.24$ \\
\hline \multirow[t]{5}{*}{ Control } & $\mathrm{C}_{1_{6 \mathrm{WK}}}$ & $225.04 \pm 10.09$ & $24.00 \pm 7.84$ & $1.21 \pm 0.31$ \\
\hline & $\mathrm{E}_{16 \mathrm{WK}}$ & $230.32 \pm 20.30$ & $24.20 \pm 4.09$ & $0.97 \pm 0.05$ \\
\hline & $\mathrm{T}_{16 \mathrm{WK}}$ & $219.72 \pm 8.31$ & $18.60 \pm 3.05$ & $1.29 \pm 0.32$ \\
\hline & $\mathrm{C}, \mathrm{E}, \mathrm{T}_{16 \mathrm{WK}}$ & $227.68 \pm 9.97$ & $22.40 \pm 6.58$ & $1.39 \pm 0.37$ \\
\hline & $\mathrm{DW}_{16 \mathrm{WK}}$ & $233.30 \pm 6.24$ & $26.00 \pm 7.11$ & $1.14 \pm 0.23$ \\
\hline
\end{tabular}

All values are expressed as mean \pm standard deviation; $\mathrm{b} p<0.05$; D: diameter of seminiferous tubule and NA: number of profiles per unit area of seminiferous tubule; WK: Weeks; MC8WK: $50 \mathrm{mg} / 100 \mathrm{~g}$ of Momordica charantia extract given for a duration of 8wks; C8WK: Vitamin C treated for 8WK; E8WK: Vitamin E treated for 8WK; T8WK: Testosterone replacement for 8WK; C, E, T8WK: Vitamins C, E \& Testosterone treated simultaneously for $8 \mathrm{WK} ;+$ : Concurrently; - : Pretreated afterwards.

The rats that were fed $M C$ alone and those pre-treated prophylactically with test solutions before administration of the extract and showed similar result (significant decrease in mean diameter and cross sectional area of the seminiferous tubules $p<0.05$ ). On the other hand there was an increase in the number of profiles per unit area, length density and numerical density of the seminiferous tubules in these groups of rats. These data implies a depleted germinal epithelium responsible for the production of luminal fluids an essential prerequisite for spermatogenesis (Heinlein \& Chang, 2002). Besides, these animals also had an altered volumetric analysis (significantly reduced testicular volumes compared to control; $\mathrm{p}<0.05$ ). This means an inhibition of the testicular protein synthesis and wide spread damage (Keel \& Abney, 1980). It also suggests significant reduction in the interstitium due to the destruction of the Leydig cells. The latter are endocrine cells responsible for the production of testosterone (de Kretser, 2007). The size of the testicular interstitium normally correlates positively with the number of Leydig cells, which in turn correlates positively with the testicular level of testosterone (Castro et al., 2002). Similarly, the testicular volume has been shown to correlate positively with testicular function (Takihara et al., 1987) as well as the testosterone level (Mahmoud et al., 2003). It therefore consistent to imply that the decreased testicular volume resulted in decreased sperm production (count and motility). Although it is not entirely possible to predict the likely consequences of these changed geometric relationships on tubular sperm production or flow because the present morphometric data form only part of the complete picture. However other factors are clearly important. These include number of spermatogenic cells in the basal compartment, the Sertoli-Sertoli cell barrier which determines the number of cells in the adluminal compartment.

For the withdrawal, post exposure treated and modulating groups, parameters remained comparable to controls. Although data for the latter group were comparatively lower, the mean differences were not statistically significant $(p>0.05)$. This suggests that the testes of the withdrawal animals showed evidence of substantial recovery. For the post exposure treated and modulation groups an indication of testicular restoration and adaptation.

In conclusion, quantitative evidence revealed the seed extract of MC at a dose of $50 \mathrm{mg} / 100 \mathrm{~g}$ body weight to pro- 
duce reversible sterility in male S-D rats. With test solutions, histomorphometric data confirms significant attenuation of the deleterious effects of the extract on the testes with coadministration, but no prophylactics with pre-treatment. In terms of tubular function, volume and surface area are influential in determining production and transport of spermatogenic cells whilst the total volume influences supply. These data are expected to serve as a preliminary template for further comparative stereological studies on MC in understanding the male reproductive anatomy. It would spring forth new frontiers in the development of a contraceptive agent for men.

Table II. Cross sectional area, numerical and length densities of seminiferous tubules in experimental and control SpragueDawlets.

\begin{tabular}{|c|c|c|c|c|}
\hline Groups $(n=95)$ & Group detail & $A_{C}\left(x 10^{3} m^{2}\right)$ & $N_{V}\left(x 10^{-10}-m^{-3}\right)$ & $L_{V}\left(x 10^{8} m^{2}\right)$ \\
\hline Treatment & $(\mathrm{MC})_{16 \mathrm{WK}}$ & $4.20 \pm 0.27^{b}$ & $120.60 \pm 0.36^{\mathrm{b}}$ & $188.00 \pm 56.27^{b}$ \\
\hline Withdrawal & $\left(\mathrm{MC}_{8}-\mathrm{DW}_{8}\right)_{16 \mathrm{WK}}$ & $35.55 \pm 3.35$ & $8.80 \pm 0.01$ & $37.60 \pm 6.23$ \\
\hline \multirow[t]{4}{*}{ Prophylactic } & $\left(\mathrm{C}_{8}-\mathrm{MC}_{8}\right)_{16 \mathrm{WK}}$ & $6.04 \pm 0.98^{b}$ & $131.50 \pm 0.16^{b}$ & $208.50 \pm 23.23^{b}$ \\
\hline & $\left(\mathrm{E}_{8}-\mathrm{MC}_{8}\right)_{16 \mathrm{WK}}$ & $4.08 \pm 0.37^{\mathrm{b}}$ & $125.50 \pm 0.02^{b}$ & $193.00 \pm 9.31^{\mathrm{b}}$ \\
\hline & $\left(\mathrm{T}_{8}-\mathrm{MC}_{8}\right)_{16 \mathrm{WK}}$ & $4.33 \pm 0.70^{\mathrm{b}}$ & $114.25 \pm 0.09^{b}$ & $180.00 \pm 7.66^{\mathrm{b}}$ \\
\hline & $\left(\mathrm{C}, \mathrm{E}, \mathrm{T}_{8}-\mathrm{MC}_{8}\right)_{1}{ }_{6 \mathrm{WK}}$ & $5.31 \pm 1.57^{b}$ & $77.25 \pm 0.21^{\mathrm{b}}$ & $133.50 \pm 39.20^{b}$ \\
\hline \multirow[t]{4}{*}{ Post Exposure Treated } & $\left(\mathrm{MC}_{8}-\mathrm{C}_{8}\right)_{16 \mathrm{WK}}$ & $46.45 \pm 21.57$ & $16.25 \pm 0.05$ & $87.33 \pm 7.57$ \\
\hline & $\left(\mathrm{MC}_{8}-\mathrm{E}_{8}\right)_{6 \mathrm{WK}}$ & $34.73 \pm 3.19$ & $18.75 \pm 0.10$ & $81.00 \pm 39.48$ \\
\hline & $\left(\mathrm{MC}_{8}-\mathrm{T}_{8}\right)_{16 \mathrm{WK}}$ & $43.90 \pm 18.19$ & $10.50 \pm 0.03$ & $48.00 \pm 12.64$ \\
\hline & $\left(\mathrm{MC}_{8}-\mathrm{C}, \mathrm{E}, \mathrm{T}_{8}\right)_{16 \mathrm{WK}}$ & $40.07 \pm 3.41$ & $10.20 \pm 0.01$ & $48.00 \pm 6.78$ \\
\hline \multirow[t]{4}{*}{ Modulating } & $(\mathrm{MC}+\mathrm{C})_{16 \mathrm{WK}}$ & $24.87 \pm 2.11$ & $26.33 \pm 0.11$ & $98.00 \pm 42.76$ \\
\hline & $(\mathrm{MC}+\mathrm{E}) 1_{6 \mathrm{WK}}$ & $26.87 \pm 1.78$ & $20.40 \pm 0.06$ & $78.80 \pm 25.44$ \\
\hline & $(\mathrm{MC}+\mathrm{T})_{16 \mathrm{WK}}$ & $25.14 \pm 0.25$ & $16.00 \pm 0.04$ & $58.80 \pm 12.21$ \\
\hline & $(\mathrm{MC}+\mathrm{C}, \mathrm{E}, \mathrm{T})_{1_{6 \mathrm{WK}}}$ & $31.48 \pm 0.63$ & $13.50 \pm 0.04$ & $55.00 \pm 14.46$ \\
\hline \multirow[t]{5}{*}{ Control } & $\mathrm{C}_{16 \mathrm{WK}}$ & $39.84 \pm 3.52$ & $10.60 \pm 0.04$ & $48.00 \pm 15.68$ \\
\hline & $\mathrm{E}_{16 \mathrm{WK}}$ & $41.93 \pm 7.50$ & $10.60 \pm 0.01$ & $48.40 \pm 8.17$ \\
\hline & $\mathrm{T}_{16 \mathrm{WK}}$ & $37.96 \pm 2.81$ & $8.40 \pm 0.02$ & $37.20 \pm 6.10$ \\
\hline & $\mathrm{C}, \mathrm{E}, \mathrm{T}_{16 \mathrm{WK}}$ & $40.78 \pm 3.59$ & $10.60 \pm 0.03$ & $44.80 \pm 13.16$ \\
\hline & $\mathrm{DW}_{16 \mathrm{WK}}$ & $42.43 \pm 2.88$ & $11.20 \pm 0.03$ & $52.00 \pm 14.21$ \\
\hline
\end{tabular}

All values are expressed as mean \pm standard deviation; bp < 0.05 ; Wk: weeks; MC 8 wks: $50 \mathrm{mg} / 100 \mathrm{~g}$ of Momordica charantia extract given for a duration of 8wks; C8WK: Vitamin C treated for 8 wk; E8WK: Vitamin E treated for 8wks; T8WK: Testosterone replacement therapy for 8wks; C, E, T8wk: Vitamins C, E \& Testosterone treated Simultaneously for $8 \mathrm{wks} ;-$ : Pre treated followed by; + : Concurrently. AC: cross sectional area, NV: numerical density and LV: length density of seminiferous tubules.

YAMA, O. E.; DURU, F. I.; OREMOSU, A. A.; NORONHA, C. C. \& ABAYOMI, O. Evaluación estereológica de los efectos de Momordica charantia, antioxidantes y testosterona sobre los túbulos seminíferos de rata. Int. J. Morphol., 29(3):1064-1068, 2011.

RESUMEN: El consumo ubicuo de Momordica charantia ha girado en torno a su potencial participación en el alivio de dolencias. El objetivo fue estudiar los efectos del extracto de la semilla de Momordica charantia (MC), ácido ascórbico (C), alfa-tocoferol (E) y testosterona (T) sobre parámetros histomorfométricos en testículos de ratas. Noventa y cinco ratas machos Sprague-Dawley (S-D) maduras (6-8 semanas de edad) fueron asignadas al azar en seis grupos. Grupo I: alimentados con MC durante 16 semanas. Grupo II: MC administrado durante 8 semanas, luego agua destilada por otras 8 semanas. Grupo III: C, E, T administrados junto a una combinación de las tres soluciones de prueba (CET) durante 8 semanas y luego alimentados con MC por otras 8 semanas. Grupo IV: MC inicialmente durante 8 semanas y posteriormente C, E, T y CET por otras 8 semanas. Grupo V: alimentado al mismo tiempo con el extracto, C, E, T y CET durante 8 semanas. Grupo VI (control): administrado con C, E, T, CET y agua destilada durante 16 semanas. Las dosis de MC, C, E y T fueron de $50 \mathrm{mg} / 100 \mathrm{~g}$ de peso corporal/oral/día, 0,01, 20,0 y $0,05 \mathrm{mg} / \mathrm{kg}$. Los animales fueron sacrificados y se estimó el volumen de los testículos. El diámetro, área de sección transversal (AC), el número de perfiles por unidad de área $\left(\mathrm{N}_{\mathrm{A}}\right)$, la densidad de longitud $\left(\mathrm{L}_{\mathrm{v}}\right)$ y la densidad numérica $\left(\mathrm{N}_{\mathrm{v}}\right)$ de los túbulos seminíferos fueron determinados. Los volúmenes medio testicular, diámetro de túbulos y AC mostraron una disminución significativa $(\mathrm{p} \leq 0,05)$ en los grupos I y III en comparación con los controles. Al quitar MC, los valores se recuperaron al valor basal de control. Los grupos IV y V, no fueron significativamente diferentes de los controles $(\mathrm{p} \leq 0,05)$. Hubo una diferencia significativa $(\mathrm{p} \leq 0,05)$ con aumento de la NA, LV y NV de los túbulos seminíferos de los grupos I y III en comparación con los controles. Los datos histomorfométricos apoyan la reversibilidad de los efectos nocivos de la MC en los testículos. 


\section{REFERENCES}

Acott, C. The diving "Law-ers": A brief resume of their lives. South Pacific Undersea Medical. Society Journal, 29(1):39-42, 1999.

Baddeley, A. J.; Gundersen, H. J. \& Cruz-Orive, L. M. Estimation of surface area from vertical sections. $J$. Microsc., 142(Pt 3):259-76, 1986.

Castro, A. C.; Berndtson, W. E. \& Cardoso, F. M. Plasma \& testicular TT level, VV \& number of Leydig cells and spermatogenic efficiency of rabbits. Braz. J. Med. Biol. Res., 35(4):493-8, 2002.

Cruz-Orive, L. M. On the precision of systematic sampling: A review of Matheron's transitive methods. J. Microsc., 153(3):315-33, 1989.

de Kretser, D. M. Endocrinology of the Male Reproductive System. Avalaible in: http://www.endotext.org/male/ male1/maleframe1.htm

Fakin, H.; MacLusky, N.; DeCherney, A.; Wallaimann, T. \& Huszar, G. Enhancement of human sperm motility and velocity in-vitro effect of calcium and creatine phosphate. Fertil. Steril., 46(5):938-44, 1986.

Gilliland, K. O.; Freel, C. D.; Lane, C. W.; Fowler, W. C. \& Costello, M. J. Multilamellar bodies as potential scattering particles in human age-related nuclear cataracts. Mol. Vis., 7:120-30, 2001.

Gundersen, H. J. Notes on the estimation of the numerical density of arbitrary profiles. The edge effect. J. Microsc., 111:219-23,1977.

Gundersen, H. J. \& Jensen, E. B. The efficiency of systematic sampling in stereology and its predictions. J. Microsc., 147(Pt 3):229-63, 1987.

Heinlein, C. \& Chang, C. Androgen receptor (AR) coregulators: an overview. Endocr. Rev., 23(2):175-200, 2002.

Helzlsouer, K. J.; Huang, H. Y.; Alberg, A. J.; Hoffman, S.; Burke, A.; Norkus, E. P.; Morris, J. S. \& Comstock, G. W. Association between alpha-tocopherol, gammatocopherol, selenium, and subsequent prostate cancer. J. Natl. Cancer Inst., 92(24):2018-23, 2000.

Henshaw, P. S. Physiologic control of fertility. Science, 117(3048):572-82, 1953.
Howard, V. \& Reed, M. G. Unbiased Stereology: ThreeDimensional Measurement in Microscopy. New York, Taylor and Francis, 2005.

Hull, E. M. \& Dominguez, J. M. Sexual behavior in male rodents. Horm. Behav., 52(1):45-55, 2007.

Jegou, B.; Pineau, C. \& Toppari, J. Spermatogenesis in vitro in Mammals. In: Assisted Reproductive Technology: Accomplishments and New Horizons. De Jonge, C.J. and C.L.R. Barratt (Eds.). Cambridge, Cambridge University Press, 2002.

Keel, B. A. \& Abney, T. O. Influence of bilateral cryptorchidism in the mature rat: Alterations in testicular function and serum hormone levels. Endocrinology, 107(4):1226-33, 1980.

Kessopoulou, E.; Powers, H. J.; Sharma, K. K.; Pearson, M. J.; Russell, J. M.; Cooke, I. D. \& Barratt, C. L. A doubleblind randomized placebo cross-over controlled trial using the antioxidant vitamin $\mathrm{E}$ to treat reactive oxygen species associated male infertility. Fertil. Steril., 64(4):825-31, 1995.

Koller, E. Diplomarbeit Javanese medicinal plants used in rural communities. Fakultät für Lebenswissenschaften, Universität Wien, 2009. Available in: http:// othes.univie.ac.at/5503/

Mahmoud, A. M.; Goemaere, S.; El-Garem, Y.; Van Pottelbergh, I.; Comhaire, F. H. \& Kaufman, J. M. Testicular volume in relation to hormonal indices of gonadal function in community-dwelling elderly men. J. Clin. Endocr. Metab., 88(1):179-84, 2003.

Malaka, S. L. O. Personal Communication. Department of Zoology. Lagos, University of Lagos, 2005.

Mayhew, T. M. A review of recent advances in stereology for quantifying neural structure. J. Neurocytol., 21(5):313-28, 1992.

Mishra, M. \& Acharya, U. R. Protective action of vitamins on the spermatogenesis in lead-treated Swiss mice. $J$. Trace Elem. Med. Biol., 18(2):173-8, 2004.

Mouton, P. R. Principles and Practices of Unbiased Stereology: An introduction for Bioscientists. Baltimore, The Johns Hopkins University Press, 2002. 
YAMA, O. E.; DURU, F. I.; OREMOSU, A. A.; NORONHA, C. C. \& ABAYOMI, O. Stereological evaluation of the effects of Momordica charantia, antioxidants and testosterone on seminiferous tubules of rat. Int. J. Morphol., 29(3):1062-1068, 2011

Naseem, M. Z.; Patil, S. R.; Patil, S. R.; Ravindra \& Patil, R. S. Antispermatogenic and androgenic activities of Momordica charantia (Karela) in albino rats. $J$. Ethnopharmacol., 61(1):9-16, 1998.

Osinubi, A. A.; Ajala, M. O.; Noronha, C. C. \& Okanlawon, A. O. Quinine lowers serum and testicular testosterone in adult Sprague-Dawley rats. Afr. J. Med. Sci., 35(4):425-30, 2006.

Østerby, R. \& Gundersen, H. J. G. Stereological estimation of capillary length exemplified by changes in renal glomeruli in experimental diabetes. In: Stereology and Morphometry in Electron Microscopy: Problems and Solutions. Reith, A. R. \& Mayhew, T. M. (Eds.). Hemisphere, New York, 1988. pp.113-22.

Rao, M.; Narayana, K.; Benjamin, S. \& Bairy, K. L. Lascorbic acid ameliorates postnatal endosulfan induced testicular damage in rats. Indian J. Physiol. Pharmacol., 49(3):331-6, 2005.

Raintree Nutrition, Tropical Plant Database. Database File for: Bitter Melon (Momordica charantia). 2008. http:// www.rain-tree.com/bitmelon.htm

Rolf, C.; Cooper, T. G.; Yeung, C. H. \& Nieschlag, E. Antioxidant treatment of patients with asthenozoospermia or moderate oligoasthenozoospermia with high-dose vitamin $\mathrm{C}$ and vitamin $\mathrm{E}$ : a randomized, placebo-controlled, double-blind study. Hum. Reprod., 14(4):1028-33, 1999.

Sönmez, M.; Türk, G. \& Yüce, A. The effect of ascorbic acid supplementation on sperm quality, lipid peroxidation and testosterone levels of male Wistar rats. Theriogenology, 63(7):2063-72, 2005.

Takihara, H.; Cosentino, M. J.; Sakatoku, J. \& Cockett, A. T. Significance of testicular size measurement in andrology: II. Correlation of testicular size with testicular function. J. Urol., 137(3):416-9, 1987.

Walum, E. Acute oral toxicity. Environ. Health Perspect., 106(suppl. 2):497-503, 1998.

World Medical Association \& American Physiological Society. Guiding principles for research involving animals and human beings. Am. J. Physiol. Regul. Integr. Comp. Physiol., 283(2):R281-3, 2002.
Correspondence to:

Dr. Yama Oshiozokhai Eboetse

Department of Anatomy

Faculty of Basic Medical Sciences

College of Medicine of the University of Lagos

P.M.B. 12003

Lagos

NIGERIA

Telephone: $234-809821251$

234-8160774976

Email: dro_yama@yahoo.com

Received: 07-12-2010

Accepted: 14-06-2011 